\title{
5-30-2015
}

\section{Genocide's Aftermath: Neostalinism in Contemporary Crimea}

Greta Uehling

University of Michigan - Ann Arbor

Follow this and additional works at: https://digitalcommons.usf.edu/gsp

\section{Recommended Citation}

Uehling, Greta (2015) "Genocide's Aftermath: Neostalinism in Contemporary Crimea," Genocide Studies and Prevention: An International Journal: Vol. 9: Iss. 1: 3-17.

DOI:

http://dx.doi.org/10.5038/1911-9933.9.1.1273

Available at: https://digitalcommons.usf.edu/gsp/vol9/iss1/4

This Articles is brought to you for free and open access by the Open Access Journals at Digital Commons @ University of South Florida. It has been accepted for inclusion in Genocide Studies and Prevention: An International Journal by an authorized editor of Digital Commons @ University of South Florida. For more information, please contact digitalcommons@usf.edu. 


\title{
Genocide's Aftermath: Neostalinism in Contemporary Crimea
}

\author{
Greta Uehling \\ University of Michigan \\ Ann Arbor, MI, USA
}

\begin{abstract}
The Crimean Tatars' genocide is one of the clearest, and yet least studied of twentieth-century genocides. This article explores that genocide's aftermath, beginning with the Crimean Tatars' attempts to reinscribe their presence in their historic homeland following the 1944 deportation. The ongoing contestations over the past are examined here as a historical habitus informing attitudes and behavior in the present. Drawing on unparalleled interview data with the Russian-speaking population in Crimea, I explore the durability and ontological resonance of constructions of Tatars as traitors both past and present. Ethnographic insight into the local understandings that feed exclusion, discrimination, and hatred enhance our understanding of genocide as a social process. Given the lack of either guilt or shame regarding the 1944 deportation, I suggest that Crimea currently lacks the cognitive and affective foundation to create a more inclusive future.
\end{abstract}

Keywords: Genocide, Stalin, Crimea, Crimean Tatars, ethnic cleansing, commemoration, deportation, ontological resonance

The Crimean Tatars' genocide is one of the clearest, and yet least studied twentieth-century genocides. The definition used here is an inclusive one, best summarized by Alexander Hinton as "the more or less coordinated attempt to destroy a dehumanized and excluded group of people because of who they are." ${ }^{1}$ The death toll as a result of the 1944 deportation was catastrophic: 46 percent of the population is believed to have perished at that time. ${ }^{2}$ In addition to this physical destruction, efforts were made to cleanse all traces of them from the Crimean landscape, and to ensure the assimilation of survivors in places of exile. Analyzing these and subsequent events within the framework of critical genocide studies reveals the treatment of the indigenous Crimean Tatars as an ongoing social practice and technology of power on the part of first the Russian and then the Soviet regimes. ${ }^{3}$

The systematic erasure of the Crimean Tatars was holistic in nature. Crimean Tatar place names were changed to Soviet ones; mosques were turned into movie theatres (or worse); homes, livestock and gardens were given away; and mention of Crimean Tatars was deleted or abbreviated in reference works. Crimean Tatars were not allowed to reside in, or speak of, their homeland. It wasn't even possible to preserve a Crimean Tatar identity in personal documents. In Central Asia, before efforts to assimilate the survivors were underway, Crimean Tatars lived in a Special Settlement regime in which tens of thousands died of malnutrition, dehydration, and disease. They were also demonized. To give but one example, Crimean Tatars describe how children's heads were checked for horns by their Central Asian school teachers.

This article unfolds in several steps. Considering that one component or aftermath of genocide is the attempt to erase the group from official history, I explore sites of memory, especially public commemoration. Although the ability of Crimean Tatars to commemorate their past as part of independent Ukraine at first suggests resilience, their efforts to reinscribe their presence on the peninsula and regain their rights have been met with opposition and resistance. Public commemorations interest me because they are one way in which competing interpretations of history become audible or legible and are then contested. Two insurrections of subjugated knowledge as part of independent Ukraine, billboards and a film, demonstrate these contestations. That the Crimean population, for the most part, does not recognize the treatment of the Crimean Tatars as genocide at all calls for deeper analysis. In the next part of the paper, I explore the thoughts and emotions behind the antipathy that continues to be directed at this indigenous people. Ethnographic insight into the local understandings that feed exclusion, discrimination, and hatred will enhance our understanding of genocide as a social process. My approach extends the work of other scholars of genocide by suggesting there is a historical habitus, or ingrained 
way of interpreting and embodying the past. These interpretations are fortified by what Hinton has called the ontological resonance of genocide. In Crimea, this ontological resonance manifests in categorical distinctions of Crimean Tatars as dangerous Others. Finally, I show how the postannexation treatment of the Crimean Tatars by local and Russian Federation authorities shows an effort to restructure relations among the living yet again, in part by circumscribing interpretations of the past. Taken together, this exploration leads me ask whether we are witnessing what scholars of genocide would call an extended aftermath, or priming for a new round.

\section{Methods}

This article is based on long-term fieldwork conducted in Crimea in 1995, 1997-98, 2001, 2004, and 2011, when I lived and worked among the indigenous Crimean Tatar population. During the 1997-98 fieldwork, I lived in both Central Asia, where the majority of Crimean Tatars remaining in diaspora and their descendants reside, and in Crimea. The ethnography published in 2004 did not delve deeply into the views of Russians in Crimea. This article begins to fill that gap. I returned in 2013 and, struck by signs of neo-Stalinism, collected the data presented here.

The ethnographic fieldwork carried out in May and June 2013 sought to better understand how and why Tatarophobia, or xenophobia had become so prevalent on the peninsula. During the fieldwork, I gathered several kinds of data, interpolated here. First, unstructured interviews with political and cultural leaders, school teachers and principals, newspaper editors, journalists, and civil society monitors enabled me to begin tracking the ground level processes through which shared interpretations were being formed. Second, taped, semi-structured interviews conducted with a stratified sample of sympathizers with the Russian Federation ${ }^{4}$ (ethnic Russians and mixed Russian and Ukrainians) using visual images of Stalin to elicit responses provided another layer of information. These data are not intended to be representative: my objective is rather to reveal some of the deeper layers informing the abysmal treatment of the Tatars that are obscured in other accounts. I used visual prompts because as Plamper has shown, reverence for Stalin was "overwhelmingly a visual phenomenon, tailored to a population whose mental universe was shaped primarily by images as opposed to written words." ${ }^{5}$ The deep psychological and spiritual importance of images of the so-called father of peoples is clear considering that Stalin portraits were often hung in the corner of the home that had previously been reserved for icons.

In 2013, I also drew on a third source of information: participation in a number of commemorative activities related to the Day of Mourning. The interviews and participant observation in Crimea upon which the core of my argument is built are supplemented by ongoing communication with consultants in the region, as well as close attention to Crimean Tatars' news reporting available on the Internet today.

\section{Aftermaths: Independent Ukraine}

Any country emerging from a totalitarian, genocidal, or war-torn past must confront questions about how to frame and incorporate that past while designing a better future. As Nanci Adler has argued, "The process of fashioning a good future out of a 'bad past' is tricky and may require the creation of a 'usable past' for the national narrative." ${ }^{\prime \prime}$ The field of reconciliation studies suggests there are multiple layers and approaches here, including acknowledgement, apology, truth, justice, and reparations. ${ }^{7}$ And yet, post-Soviet Russia only made limited efforts to confront its Stalinist past, seeming to prefer to suppress memories of repression. ${ }^{8}$ As a result, surviving victims of Stalinism have been insufficiently acknowledged. Adler sees the prevalence of the state-sponsored narrative over the victims' counter-histories as part of a larger failure to create adequate transitional justice mechanisms and move toward full-fledged civil society. From her perspective, Russia has not yet created a space for what she calls "engaging dialogues," that could lead to inclusive history. ${ }^{9}$

Within a framework of critical genocide studies, we can go farther. Not only has their been insufficient acknowledgement, but the Crimean Tatar genocide is treated first by Soviet and now Russian Federation authorities as something the Crimean Tatars brought upon themselves. Locals allege the Crimean Tatars' punishment was justified, even though there is no morally or ethically sound justification for the treatment they received. In part, this is a result of diametrically opposed interpretations of history. Russians and those of mixed Russian and Ukrainian heritage who are 
pro-Russia tend to deploy an idiom that legitimatizes their presence by referencing the fact that Crimea was a part of Russia from 1783 until 1954, and reiterate the charges of treason during the Nazi occupation of Crimea. The Crimean Tatars counter this by pointing to what the charges elide, which is that members of all ethnic groups contributed to the Nazi occupation, and that these are not the people who were punished by the 1944 deportation, which carried away innocents. That Crimean Tatars soldiers fought (and gave their lives) on the Soviet front and were demobilized into exile is of course a moral outrage. They also emphasize their autochthonous origins on the peninsula, long before Ekaterina II annexed the peninsula. Thus it is important to recognize the extent to which different ethnic groups-and here I will focus on the pro-Russian contingent and Crimean Tatars - have competing idioms for relating to, and when necessary justifying their presence on, the peninsula they share..$^{10}$ While their idioms overlap on concern with the meaning of homeland, patriotism, and treason, they have very different reference points.

It is worthwhile to contrast the situation in the Russian Federation with post-genocidal settings where transitional justice mechanisms, however imperfect or limited, have been established. For example, Molly Andrews has argued the South African Truth and Reconciliation Commission created a national narrative and ultimately a common framework for the whole country to understand the past. ${ }^{11}$ She suggests that (again, in spite of many shortcomings) the South-African commission managed to forge a dialogue between official and personal narratives, and to formulate an inclusive history. A rich line of research into the reconciliation process explores the nuances of this process in a variety of countries. ${ }^{12}$

As a part of Ukraine, Crimea occupied a volatile and yet fertile position between these two variants. An insurrection of previously subjugated knowledges led, while the Autonomous Republic of Crimea was part of Ukraine, to writing the 1944 deportation back into history books, putting the minarets back on the mosques, and erecting multiple public monuments to commemorate Crimean Tatar military heroes and cultural leaders. While the process was far from complete, and characterized by failures and frustrations, it is important to recognize the extent to which Crimean Tatars were able to reinstate their rightful presence on the peninsula, and reinscribe their history on the landscape they hold sacred.

Even as they became legible on the Crimean peninsula, however, it became a landscape of hatred and distrust as monuments and memorials were marked with swastikas or other xenophobic graffiti, and groups clashed over such matters as placing a market on a Crimean Tatar sacred site. As part of Ukraine, hostility against Crimean Tatars included attacks and pogroms against Crimean Tatar settlements and property in 2004. An attack on a Crimean Tatar settlement backed by special Ukrainian Berkut riot police in January and November, 2007; the attack and beating of Crimean Tatars on the Ay-Petri plateau in November 2007; and vandalism of Crimean Tatar cemeteries and memorials in Zaprudne, Zuya. Saq, Bagcasaray, Nyznohirskyi and many other locales. The Foundation for Research and Support of Indigenous Peoples that tracks these activities concluded vandalism is more the rule than the exception. ${ }^{13}$

How to understand these contestations? Within the framework of critical genocide studies, a Foucauldian genealogy with its concepts of counter-memory and counter-history helps to decipher the struggle over commemoration and competing visions of the past. ${ }^{14}$ This approach is relevant because as part of Ukraine, cross currents of power and resistance appeared to be reshaping the field of commemoration and expanding the space for remembering different, sometimes painful aspects of the past. By way of background, counter-histories try to undo the silences imposed by official histories, and to undermine the unity and continuity that dominant histories produce. The ability to identify omissions and to fill discursive gaps previously imposed by authorities is an important component of exercising agency and resisting both hegemonic power/knowledge frameworks and, at a more concrete level, sociopolitical subjugation.

My 2004 ethnography detailed how activists in the Crimean Tatar national movement such as Mustafa Cemilev, Reshat Cemilev, Aishe Seitmuratov, Rustem Khalilov, Izzet Khairov and many others, clearly articulated a counter-narrative explicating how the 1944 deportation violated the laws and principles of the Soviet regime, and subjected the Crimean Tatar people to decimation. They also make clear that by the time of the deportation, the Crimean Tatar people had survived not just the initial colonization, but confiscation of their property, state-induced famine, purges of clergy and 
intellectuals, and Nazi occupation. ${ }^{15}$ In a personal interview, this was aptly summarized by Mustafa Cemilev as being caught between to hegemons, neither of whom promised any protection or relief. ${ }^{16}$

What I am concerned with presently is less the historical scholarship and activism facilitating the Crimean Tatars mass return in the 1990s, than the public spaces where ordinary Crimean Tatars, Ukrainians and Russians are now interlocutors. These sites demonstrate that there is no single aftermath of genocide: it becomes a plural noun. Pro-Russian and pro-Crimean Tatar versions of the past are diametrically opposed. The differing perspectives on the past led, unquestionably, to different perspectives on the future. We now see each group has very different access to rights and resources on the peninsula as a legacy of the deportation.

\section{The Contested Past}

In spite of attempts to erase and assimilate them, the Crimean Tatars survived their exile, launched a powerful national movement, and mobilized sufficient personal and political resources to repatriate. ${ }^{17}$ Since they began returning, Crimean Tatars have struggled to reverse the effects of the literal and discursive cleansing..$^{18}$ Examples show the slow movement of a previously marginalized Crimean Tatar past into the Crimean imagined community.

One example is the commemoration of the 1944 deportation, referred to in Crimea as a "день память и скорби" or day of memory and mourning. In a move that would certainly have been quashed 20 years ago, some twelve billboards calling participants to observe the occasion were positioned across Crimea. One billboard calling for observance of the day showed an image of several intersecting lines of barbed wire and a message about the $69^{\text {th }}$ commemoration, bringing knowledge that was previously disqualified and excluded into the public space. Another billboard brings home the point even more clearly.

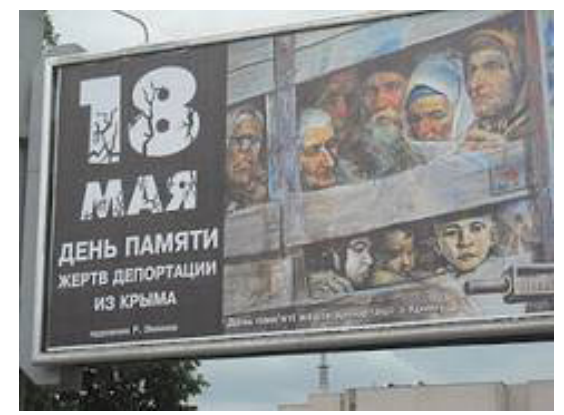

Figure 1. Billboard of Iminov painting calling for commemoration. Source: Author's photograph.

Rustem Iminov's painting of a crowded train car, once concealed in his private studio on a quiet street in Tashkent, Uzbekistan, was suddenly enlarged many times and thrust into the visual field of all drivers in Crimea, whether Russian, Ukrainian, or Crimean Tatar. The billboard makes visible how women, children, and the elderly were carried away in cattle cars, not to mention the soldiers' unfortunate demobilization. Thanks to the artist's willingness for others to use this image, it has become iconic of the Crimean Tatars' deportation. I turn to the billboards because they are one way that the Crimean Tatars can speak to other residents of Crimea with whom they might not otherwise exchange views. ${ }^{19}$

I first met Iminov and saw the painting in 1998, when he was living in Central Asia. I learned that whereas Iminov's father, also a painter, was forced to communicate his ideas cryptically in symbolic codes, Iminov succeeded in putting his mother's individual memories of deportation in public, pictorial form. ${ }^{20}$ The trajectory of this painting from a private Tashkent studio to a Simferopol billboard indexes the Crimean Tatars' own journey from silenced and exiled, to repatriated citizens of independent Ukraine. The billboards constitute an intervention into the hegemonic conception of the past that failed to register the Crimean Tatars during their absence.

A second example of the insurrection of previously subjugated knowledge, and one that generated a great deal more epistemic friction ${ }^{21}$ is provided by the 2013 release of a feature film about the 1944 deportation, Haytarma. 


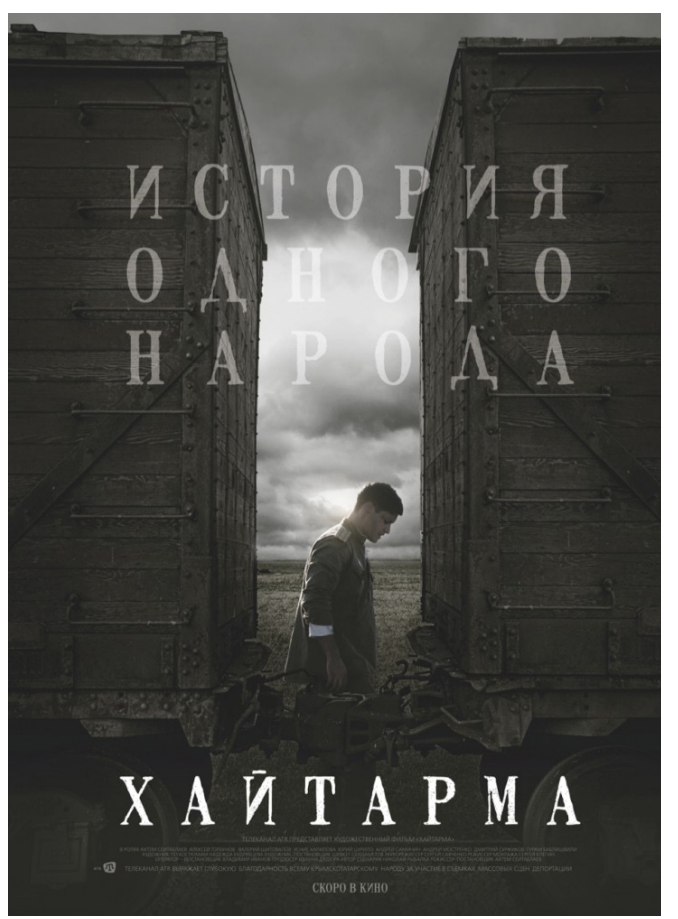

Figure 2. Promotional flyer for the film Haytarma. Source: The image is taken from the jacket of the CD, and was the flyer for the showing of the film as well.

The film is structured around the life of the half Crimean Tatar fighter pilot, Amet-Han Sultan. The film follows the protagonist through his service when he was stationed in Crimea. The major turn in the plot comes when Amet-Han Sultan is given leave to see his family on the eve of the deportation. He and two friends find themselves in Amet-Han's native village on the night of the mass deportation. We then experience a filmic representation of that terrible night.

The film has been criticized on the grounds that it uses the language and iconography of the colonizers to communicate its message. ${ }^{22}$ Admittedly, we see a colonized people taking on, and quite literally acting in, the uniform of the oppressor. While this reading of the film is valid on formal grounds, a more nuanced reading is possible if we listen to the conversations about the film among Crimean Tatars. Recalling that Crimean Tatars were banned from speaking of Crimea in exile, and that no images of the actual deportation are known to exist, the film elevated previously silenced and submerged memories of war and deportation. While perhaps not a counter-history in the sense of a full-fledged denunciation of the Soviet regime, the film does critique the Soviet's 1944 deportation. By portraying Amet-Han's bravery and patriotism fighting on the Soviet side, the film also attempts to deconstruct the racist categorization of Crimean Tatars as solely collaborators with the German occupiers, and shows ethnically-integrated villages. Like the billboards, the film fills a visual lacuna.

For younger Crimean Tatars, parents' and grandparents' stories were finally in a visual format. Crimean Tatars who acted in the film describe participation as an intense, even cathartic experience. At the premier I attended, the film was followed by stunned silence and muffled sobbing. The film also received many standing ovations by audiences in Crimea and Kyiv. It is fair to say the film punctured the silenced history of deportation and brought Crimean Tatar patriotism into public view. If respondents in my fieldwork were correct in their assessment, a page that had been left blank, and that had long complicated the mourning process, was now filled, helping to resolve some emotions about the event.

The film's release generated a great deal of epistemic friction concerning how to most accurately portray the Crimean past. The controversy began when the Consul General for the Russian Federation in Crimea, Vladimir Andreev, admonished the Russian generals trained by Amet-Han Sultan not to attend the Premier. Six of the eight surviving generals took his advice. ${ }^{23}$ 
Uehling

Mr. Andreev clarified his position publically on Crimean television. Resurrecting a trope from the Second World War (referred to as Great Patriotic War in Crimea), Andreev stated that Russia should not be represented at the premier of a film that falsifies the truth of this war. His primary argument was that the film did not grapple with the ostensibly salient theme of collaboration on the part of Crimean Tatars with the fascist occupiers. Public discourses like these are a primary way that ideologies and cultural stances are not just created, but maintained. Andreev's remark seems designed to create cultural continuity at a moment when it was threatened by change in postSoviet Ukraine. By resurrecting the old categorizations of Crimean Tatars as somehow disloyal to the homeland, Andreev re-polarized the field of commemoration in a move seemingly intended to inscribe the Soviet-era social hierarchy.

Based on the reaction in the family I was living with at the time, Andreev's comments left the Crimean Tatars feeling angry and emotionally bruised. One of my hosts stood and paced, another turned red in the face, and all three raised their voices to talk back to the TV. Andreev's remarks also set off a series of demonstrations that were publicized on the nightly news. Holding Andreev's portrait flanked by pictures of Beria and Stalin, Crimean Tatars countered the slur by pointing out the symbolic isomorphism between the present Consul General and past Soviet leaders. There were also a series of verbal duels that ricocheted through social media like Facebook.

While the Crimean Tatar contribution in the Second World War remains hotly contested in Crimea, Andreev's intolerance was not accepted, even by authorities. Ukraine's Foreign Ministry immediately requested Russian Federation authorities to evaluate the statements. In an address before the Supreme Council of the Autonomous Republic of Crimea, then Vice President of the Crimean Tatar Mejlis Refat Chubarov demanded the Russian Federation deplore the intolerant statement. The Ministry of Foreign Affairs of the Russian Federation did indeed acknowledge the statement was inappropriate, and Andreev resigned. As we can see from the conflict over Andreev's remarks, references to collaboration with the Nazi forces are particularly toxic in Crimea where, even though all the ethnic groups collaborated, Crimean Tatars have been consistently singled out as responsible. Ukraine rose, however feebly, in the Crimean Tatar defense.

While a great deal of the contemporary friction is generated by the issue of Second World War collaboration, the roots of mistrust lie deeper in the colonial past. The Russian Empire saw Crimean Tatars as uncivilized, inferior to Russians, and potentially disloyal. This references events during the Crimean War. Raids on Muscovy in the Middle Ages are also often cited today. ${ }^{24}$ In light of these analyses, Tatarophobia has less to do with the Second World War than the Crimean Tatars' long term positioning on the peninsula. Views of the peninsula's past have remained in separate, diametrically opposed, silos. While ethnic Russians see themselves as the original inhabitants of Crimea, and argue the Crimean khanate had a weak economy and was only a vassal of the Ottoman Empire, Crimean Tatars assert that the Crimean khanate was a highly civilized state in which all faiths were accepted, ethnic groups flourished, and the economy thrived. Both are of course simplified interpretations. What is more destructive is the view (whether embraced by ethnically Russian or ethnically mixed individuals) that Russian culture is superior, supranational, and provides a consolidating function. There is also an essentialism that Crimean Tatars are inherently hostile and cruel, another justification for their removal from Crimea. From a broader perspective, then, the Crimean Tatars were prefigured for predatel'stvo or treason.

\section{Neostalinism}

To reestablish the Crimean Tatar presence on the peninsula would require restructuring the worlds of meaning in which Crimean Tatars are cast as traitors or villains. Efforts during the Ukrainian period marking the anniversary of the 1944 deportation, erecting monuments to the Crimean Tatar past, and writing the 1944 deportation back into history, re-politicized space and time. ${ }^{25}$ As if obeying Newton's Third Law, for every Crimean Tatar action there was an equal and opposite reaction. A paradigmatic example is the counter-movement revalorizing Stalin in Crimea. In 2012, an organization named Essence of Time held an exhibition commemorating the $133^{\text {rd }}$ anniversary of Stalin's birth. They combined about 150 images with laudatory comments about Stalin. These were presented on large placards in the center of the capitol city where descendants of the victims of genocide would be sure to look on. The Crimean Tatar executive body, the Mejlis, spoke out during 
the planning stage, pointing out such an exhibit would be profoundly disrespectful to victims of Stalin. The exhibit took place nonetheless.

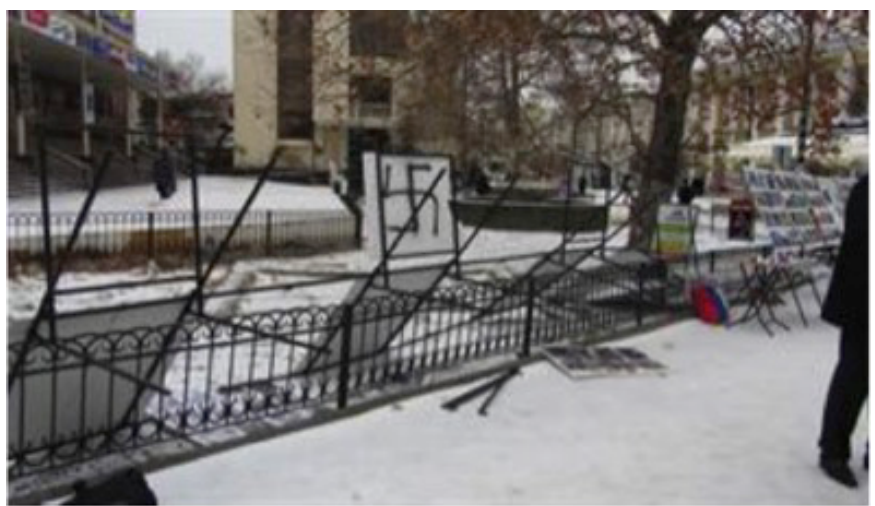

Figure 3. Stalin lauded in capitol of Crimea, 2013. Source: Информационное агентство «е-Крым» http://www.ecrimea.info

On the opening day, the Head of the International Relations department of the Mejlis went to the exhibit with the head of the Secretariat of the Crimean Parliament. ${ }^{26}$ They called on the organizers to take down the images, pointing out that Stalin was found guilty of the death of millions of people, and had personally ordered the deportation of the Crimean Tatars, a criminal act. When the organizers refused to remove the exhibit, the offended visitors dismantled the stands themselves.

Several dozen law enforcement officers present at the rally did not intervene. The authorities' non-response, effectively allowing residents of Crimea to battle for commemorative space themselves, reveals official ambivalence, or perhaps uncertainty about how to effectively moderate competing claims. As one respondent put it, "the Mayor who allowed it knew it was against the law, but in the depths of their souls, they don't want to see us here, they hate us. They know they have taken other peoples' places." ${ }^{27}$ The exhibit took place in a time and place when Stalin enjoyed fabulous public ratings. Levada Center polls showed that among other things, people credited victory in the Second World War to Stalin himself, and felt that the importance of the victory far outweighed any mistakes that were made..$^{28}$ Another survey suggested that respondents saw Stalin as one of the "most eminent figures of all time." ${ }^{29}$

How could Stalin enjoy such a long political life? Considering there was not one but two intensive efforts de-Stalinize the Soviet Union and facilitate political liberalization, this at first seems remarkable. The first attempt was after the $20^{\text {th }}$ Party speech by Nikita Krushchev, which broke a silence about Stalin's repressive regime and called for the removal of Stalin from public spaces. The second effort was part of President Gorbachev's reforms. Gorbachev recognized the need for the Soviet government to give consistent financial and moral support to people who could speak openly. Gorbachev's de-Stalinization in the 1980s faced many of the same problems that Krushchev's had in the 1960s. ${ }^{30}$ Polly Jones suggests the enduring criticisms are that de-Stalinization is a form of "de-heroization," "falsification," and "ideological deviation." ${ }^{31}$ The psychology that keeps Stalin alive aligns with the work of Freud, Derrida, and Gilroy on melancholia, helping us to understand neostalinism as an inability to distinguish between past and present. ${ }^{32}$ Freud's famous delineation of melancholia from mourning is useful here.

Why wasn't the Soviet government more successful in de-Stalinizing the country? Jones suggests that what is blocking genuine de-Stalinization is what she calls the "mutual interference" of memories of terror and memories of war victory. ${ }^{33}$ This is to say that there is a central, seemingly irresolvable tension at the core of public memory: how to celebrate the Soviet victory and confront its failures, so as to recognize the victims too? In Russia, organizations like Memorial have tried to grapple with this issue, and their work has resonated with tens of thousands of people. This is an especially fraught issue in the Autonomous Republic of Crimea, where the problem is ethnicallycharged. 


\section{Ontological Resonance}

The outward struggle over this field of commemoration is energized by what Pierre Bourdieu would call a habitus or durable disposition. Habitus is Bourdieu's notion of a "system of lasting, transposable dispositions which, integrating past experiences, functions at every moment as a matrix of perceptions, appreciations, and actions." ${ }^{34}$ Habitus is eminently historical: "The habitus, a product of history, produces individual and collective practices - more history - in accordance with the schemes generated by history." ${ }^{35}$ We can understand this as something that is simultaneously micro and macro-sociological: a neo- or pro-Stalinist disposition is acquired through a gradual process of inculcation at the same time that it reflects the social conditions in which it was acquired. A habitus is never independent of its field, what Bourdieu saw as a set of objective, historical relations, anchored by power. ${ }^{36}$ Along similar lines, in Why Did They Kill, Hinton argues that genocide is complex and involves a certain "ontological resonance" of local cultural knowledge that, through a variety of factors, rises to the level of having motivational force. Like Hinton, I am interested in the role of the patterns of being-in-the-world that are constituted over time as people engage in social practices that ultimately come to inform acts of political violence, whether the Khmer, Russian, or Soviet. ${ }^{37}$

To better understand the disposition informing the exhibit to rehabilitate Stalin in Crimea, and to glean insight into ongoing antipathy towards Crimean Tatars, I interviewed a stratified sample of respondents from the roster of the Russian Society. ${ }^{38}$ I used images of Stalin collected in Corbescero's research in Russia as prompts to elicit informants' feelings about the leader. ${ }^{39}$ The first image was a famous portrait of Stalin in uniform.

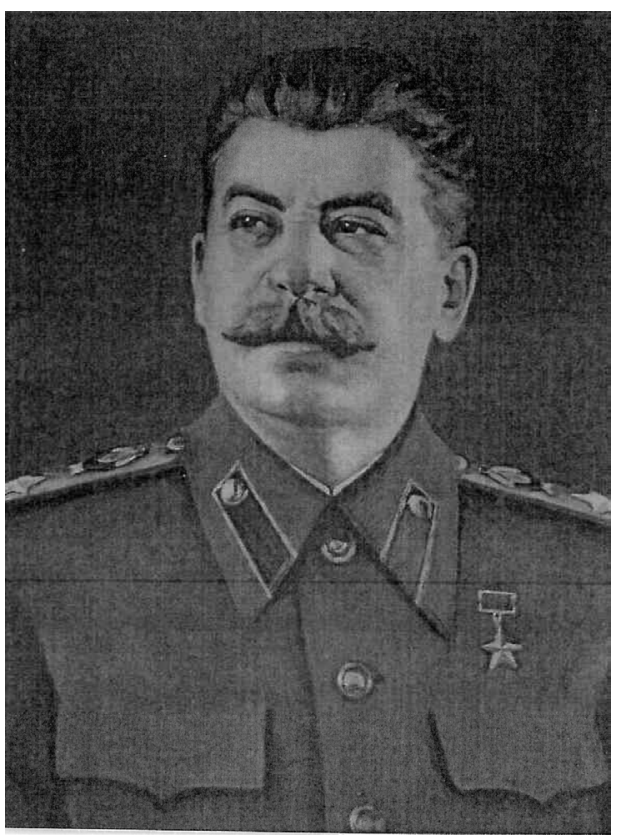

Figure 4. Portrait of Stalin by Aleksandr Laktionov. Source: Corbescero (2011).

The second was the same portrait remade as a vodka label, a third depicted the same Stalin image writ large on a bus to celebrate the $9^{\text {th }}$ of May, ${ }^{40}$ and the last image showed demonstrators each carrying an individual Stalin portrait in a demonstration. The images elicited reactions both verbal and visceral: respondents laughed and cried when they viewed the images. Their reactions suggest deep emotional connections to the past and a durable disposition integrating past experiences and present perceptions.

\section{Neither guilt nor shame}

Veneration for Stalin reverberated throughout the interviews with Russians and individuals with mixed Russian and Ukrainian heritage but embracing a pro-Russian perspective, in Crimea. 
Presented with images of the leader, respondents used expressions like "gratitude that we are alive," "pride for the activities he carried out," "empathy," "neutral," "accepting," and "this is the image of a good person," to describe their feelings. Sometimes, the thinking had twisted logic: "If he was such a tyrant, they would have shot him!" This respondent clearly had not thought through how tyranny works, or the way in which it is the very tyranny of the tyrant that protects him.

One strategy that seemed to help respondents maintain a positive image of the leader was to minimize his crimes:

How do you feel when you look at this portrait?

Respondent: How to put it into words? Empathy. Empathy that he may have overplayed his leadership somewhat. True, he was on the cruel side. ${ }^{41}$

In a dizzying moral inversion, this respondent chose to empathize with the leader, rather than his victims. In making the comment, this respondent used the word жестоковата, using a qualifier to say Stalin was "on the cruel side," shrinking massive crimes against humanity into a minor attribute. It is only in the context of this frame of mind that the crude and ultimately inaccurate binary between Russian patriotism and Tatar collaboration can be maintained. Officially sanctioned amnesia of Crimean Tatar patriotism, and willed forgetting of the true level of Stalin's crimes perpetuate this outlook.

Minimization went hand in hand with justification. Part of the justification appeared based on survival. Respondents hypothesized that what Stalin did was necessary for victory, and linked their personal survival to his tactics:

How do you feel when you look at this portrait?

Respondent: Gratitude that we are alive [starting to cry] During the war, we had nothing, nothing [explanation of things eaten to survive]. Then, after the war, my mother and I had tea with sugar in it and I will remember that tea for the rest of my life, it made such an impression after going for so long with so little. ${ }^{42}$

The survival of extreme deprivation understandably elicits gratitude. But if we juxtapose the sweetness of the tea with the death toll from Stalin's regime, the "cost" of that tea, and the respondent's apparently complete emotional disconnection from the magnitude of the crimes committed in the name of her homeland, becomes evident. Due to the secrecy surrounding the camps, the length of time that has elapsed, and the variety of means to eliminate people, an exact death toll is difficult to calculate. However, representatives of the Soviet security services gave the figure of 18 million..$^{43}$ These facts are lost to residents of Crimea when focused on reliving and recognizing victory. The neostalinist views expressed by non-Crimean Tatar informants suggest a durable disposition or habitus cultivated for decades.

Justifications for deporting innocent women, children, elderly, and war-wounded residents of Crimea were also based on the idea that the Crimean Tatars somehow deserved and, in thinking that stretches credulity, even benefitted from the deportation. Russian justifications tend to be dissociated from the reality of genocide. As one example:

If Stalin decided it, then that means it was necessary. And the thing is, they [Crimean Tatars] slaughtered whole villages under the fascists. He [Stalin] cast them out, but he sent them to a warmer climate! It was a radical measure that was correct at the time. See how spiteful [Crimean Tatars] are to complain? They left a place where life was good. ${ }^{44}$

The place they left is of course Central Asia in the 1980s and 1990s. The sentiments expressed here are widespread in Crimea, where the non-Crimean Tatar population often alleges that it was "humanitarian" to deport the Tatars to a warm climate rather than exterminating them. The acceptance of Stalin's act emerging in these interviews reveals the affective and cognitive substrate, the habitus informing events like the commemoration of Stalin in the center of Simferopol in 2012, and subsequent events. 
Writing about Crimea, Rory Finnin explores the potential of poetry to shift one's perspective from focusing on the victor to a more empathic position in relation to victims. He explores how two poems, one by Chichibabin and one by Nekipelov, create receptivity to perceive the mass deportation of innocents (collaborators are believed to have been evacuated with the retreating German army) as one of Stalin's greatest crimes. Thinking of more tolerant and empathic segments of the population than I spoke with, Finnin suggests that a deep reading of the poems can engage a reader in "an act of guilt-processing conducive to committed activism." ${ }^{45}$ Finnin thinks literary works can prompt recognition of the complicity of Soviet citizens in the deportation. The twist is that the process is more likely to succeed when hearing from some subject positions rather than others: if the literary work comes from the victimized community, it is liable to evoke shame, which is apt to prompt to avoidance. Guilt, on the other hand, tends to mobilize efforts to repair and make amends.

It is unlikely that the affective and cognitive recognition of Stalin's act as a crime will occur in a Crimean society overshadowed by accusations of treason. In the 2013 fieldwork, Crimean Tatars frequently lamented the absence of anything resembling guilt. On the contrary, informants' statements seemed to re-sacralize ${ }^{46}$ Stalin's authority, perhaps as a way to maintain a dominant position in Crimean society and to reanimate the sense of victory and empowerment that came with his rule. Articulating her response to the picture of Stalin in uniform, a Russian informant stated:

He was, is, and will always be forever a great leader. It's like he is sacred and you can't just erase that from your heart. Millions of people died with his name on their lips. How can you throw that away? It's too late to change anything now [weeping]. I am sorry about the tears but this is the life I lived. ${ }^{47}$

The reverence for Stalin surfacing in certain segments of the population suggested ongoing enchantment with the leader. I asked this respondent if she thought Russian or Ukrainian residents of Crimea who were not deported or were brought in after the war to take Crimean Tatars' places felt a sense of guilt.

Me personally? No! Why would I feel guilty? I understand many Russians and Ukrainians live in Tatars homes. I myself live in a Tatar's home! But it was vacant at the time we came. ${ }^{48}$

What this informant had disassociated from is why the home was vacant when she and her mother arrived. As actors on a field of public remembering, these respondents used victory to rationalize the price paid by the Crimean Tatar people.

It is not coincidental that the statements made here were uttered in the Simferopol headquarters of the Russian Society. Respondents spoke under posters of Sergei Aksyonov who was then head of the Russia Unity party, and was elected Prime Minister in March 2014. In other words, these are the sentiments of some of his constituency. What I did not know in 2013 was how accurately they foreshadowed the poor treatment of Crimean Tatars accompanying the annexation. An anthropological approach is valuable here because it reveals the ontological resonance of Crimean Tatars as Other, both past and present. The constructions of Crimean Tatars as traitors demonstrate the ontological resonance of categories established in the Russian colonial period. It also foreshadows the treatment of the Crimean Tatars following annexation. The time period following 2014 annexation was marked by a range of human rights abuses: Crimean Tatars were banned from assembling, and threatened, imprisoned, and exiled when they dared to express dissent. Crimean Tatars were harassed with searches and seizures in their homes, schools and mosques. Even worse, there have been arrests, arbitrary detentions, and disappearances. ${ }^{49}$

Reflecting on this pocket of disavowal and amnesia, I asked Mustafa Cemilev what explains the lack of empathy for Crimean Tatars. His insights suggest links between the official history and popular sentiment, and between denial and fear.

Tatarphobia is understandable given the kind of propaganda that people were stuffed with since the Crimean Tatars were deported. Plus, this propaganda gave them some spiritual 
peace considering they were living in our homes. There is also a fear that maybe what happened to the Tatars will happen to them. ${ }^{50}$

The characterization of Crimean Tatars as 'traitors who sold the motherland' has proven impervious to change. It provides an expedient phrase that encapsulates the ontological resonance prefiguring Crimean Tatars as different, as guilty, and as deserving of punishment.

The challenges associated with acknowledging the genocide are not unique to Crimea: we see very similar issues arising in other settings. Theodor W. Adorno and Max Horkheimer provide important thinking on this topic by suggesting it was a complex defense mechanism against memory that prevented Germans after the Second World War from experiencing feelings of guilt. ${ }^{51}$ These scholars saw the disavowal of any complicity, as well as admiration for Adolf Hitler, as the core of a constellation of psychological symptoms including antisemitism. Psychoanalysts have developed this line of thinking to explore how guilt and shame, as well as defenses against them, are passed inter-generationally. ${ }^{52}$ Katharina Rothe suggests that antisemitism should be considered a defense against empathizing with the victims in the Second World War. ${ }^{53}$

This idea presents rich possibilities for understanding dynamics in Crimea, where local residents' distrust of Tatars often seems based more on fiction than reality, ${ }^{54}$ and where, as Refat Chubarov noted in front of the Crimean Parliament at the time of Consul General Andreev's acerbic remarks, xenophobic statements have become almost fashionable in public discourse. ${ }^{55} \mathrm{I}$ suspect a similar defense may be animating ongoing anti-Tatarism in Crimea. For some residents, it may be less painful and, as Cemilev pointed out, more expedient, to valorize Stalin and disavow any benefit from his crimes. It is far more difficult, for us all, to see events from another's perspective. The demonization of Crimean Tatars enables those who make allegations of depravity or treason to elevate Stalin, fear Tatars, and avoid both guilt and shame. While some would argue against a sociocultural use of psychoanalytic concepts, I would contend, with LaCapra, that psychoanalysis is misunderstood as a psychology of the individual. He argues that its basic ideas actually connect individual and society. A strict opposition is artificial-what happens to the individual is bound up with larger social, political, and cultural processes. ${ }^{56}$

\section{Genocide as social practice}

There are a number of markers we can use to predict the future of the past in Crimea. I have already described how the Crimean Tatars were able to publically commemorate the 1944 deportation when Crimea was a part of Ukraine. If symbolic forms such as these help create and maintain social hierarchies, the billboards announcing the commemorative event in 2013 were particularly significant: the Crimean Tatars leveled, if only temporarily and incrementally, the commemorative field when they publicized their past alongside the Russian one. Russian annexation brought a very different reality to Crimea.

On one hand, Putin assured Crimean Tatar representatives who went to Moscow in May 2014 that Russia will take measures to protect Crimean Tatars and make them feel they are "full fledged masters in their own land." ${ }^{57}$ At the same time, Crimean Prime Minister Sergei Aksyonov issued a decree that banned all mass gatherings in the region, effectively outlawing the 2014 commemoration of the deportation. Aksyonov used a kaleidoscope of shifting reasons, mostly centered on national security, for his decision. ${ }^{58}$ The central square where Crimean Tatars would have gathered was fenced off, guarded by ranks of Russian riot police as well as pro-Russia so called self-defense units, and lined with armored personnel carriers. Avoiding conflict, Crimean Tatars gathered in a field near their mosque in the Ak Mechet district, just outside the capitol city of Simferopol. There, a foreshortened commemoration was carried out under the whirl of helicopter blades.

This attempt to reorganize relations among the living by banning commemoration of the dead was a way to begin the process of reordering community in post-annexation Crimea. Scholars of genocide are increasingly recognizing how technologies of power such as these make genocide not a discrete event with a beginning, middle, and end, but a social process. ${ }^{59}$ Clearly the change in power, and the status of the peninsula as part of the Russian Federation, is reconfiguring more than geopolitics. Leaders like Sergei Aksyonov, the Prime Minister and Head of the Supreme Council, 
and Natalia Poklonskaya, the chief prosecutor confirmed by President Putin, are now engaging and intervening in the social process in which the living in Crimea must struggle with the war's legacy: how, when and who to honor ${ }^{30}$ How, when, and who to mourn?

The current authorities' aims within this emotional substrate are clear in light of the ample space afforded to those wishing to commemorate Victory Day: shortly after the Crimean Tatars were banned from mourning their loss, Putin flew to Crimea to publicly commemorate Soviet victory over Nazi Germany in Sevastopol. Tens of thousands were allowed to flow into the streets, and there was a parade with over 60 military vehicles and 70 aircraft. $^{61}$ The contraction of commemorative space accorded to Crimean Tatars relative to Russians (and Russian-Ukrainians) throws into bold relief the very real imbalances of power on the peninsula that are papered over by official pronouncements of equality before the law.

The Crimean Tatar response to being banned from carrying out their usual commemoration brings us back to the link between genocide and historical memory. Genocide can be understood as an act that is directly aimed at destroying ethno-national-religious diversity and altering the social fabric of societies so as to remove unwanted traces of undesired peoples. ${ }^{62}$ This requires removing people from any sites that would physically register social memory. Refat Chubarov described the decree banning commemoration as an inhumane act, pointing out that the Crimean Tatars had essentially been forbidden to mourn their ancestors. A popular TV talk show host, Lilia Budjorova, asked rhetorically whether the authorities fully understood the meaning that the day of sorrow and remembrance has for the Crimean Tatar people. She warned that the ban would be remembered for many years, and can't be compensated for by any amount of government spending on Crimean Tatars. ${ }^{63}$ Budjurova's comments suggest that if Aksyonov wants Crimean Tatar support to secure his rule, the ban may actually be counterproductive to his aims:

Today, like tens of thousands of my compatriots, I have been banned from coming into the center of my own town to stand next to those who have lost mothers, fathers, and children. I have been banned from sharing their pain. You have taken away my right to make sure that my grandchildren know that this tragedy must never repeat itself. ${ }^{64}$

Budjurova suggested that pain can only be reduced with empathy and understanding. With this, she suggests more empathy would have set a very different tone to relations between the new authorities and the indigenous Tatars. This also jives with what we know about transitional justice. In the repertoire of effective mechanisms, the commemoration of victims is widely considered a crucial part of reconciliation with a repressive past..$^{65} \mathrm{In} 2014$, the new Crimean administration headed by Aksyonov missed an opportunity to be more accepting of all members of the society and move to a less polarized future. If the 2014 commemorations are any indication, Crimeans will again be confined to a single narrative that elides the Crimean Tatar experience.

In spite of assurances on the part of President Vladimir Putin and Aksyonov, what has transpired since annexation hardly amounts to protection of the endangered group. For one thing, there has been a rash of disappearances. In one case, a witness reported seeing two men forced into a mini-van by men in black uniforms before they disappeared. Accounts vary but according to Human Rights Watch there have been at least seven and potentially as many as 18 disappearances.$^{66}$ Officials only acknowledge four. Searches of Crimean Tatar homes became almost routine in during summer 2014. These were carried out in the name of "protecting" the people. There has also been harassment of mass media outlets: self-defense battalions comprised of men in camouflage gear and balaclavas have searched and seized broadcasting equipment at some of Crimea's major television channels. The systematic attempt to weaken the community has included banning Crimean Tatar leaders from residing in Crimea among their people. First came renowned defender of human rights, Ukrainian parliamentarian, and former Head of the Crimean Tatar Mejlis, Mustafa Cemilev. Then came the elected President or Chairman of the Mejlis, Refat Chubarov. In February 2015, acting Chairman of the Mejlis, Akhtem Chivgoz was arrested and imprisoned. These practices amount to the gradual weakening of this people through discrimination, harassment, and isolation, over time. 


\section{Conclusion}

As a result of this analysis, I hope to have contributed a deeper understanding of the Crimean Tatar genocide. I have argued that while Crimea was part of Ukraine, it experienced a volatile and yet fertile insurrection of previously subjugated knowledges. Public commemorations became a lightening rod, channeling contestations over the recent and distant past. While previous gaps and omissions were made visible, hegemonic power/knowledge frameworks continued to make one group appear better than another.

These contestations are difficult to fully appreciate without a greater understanding of the historical habitus of individuals in Crimea. Using fresh and now virtually unobtainable data, I provide an ethnographic exploration into the thoughts and feelings of a subset of the non-Crimean Tatar population, showing a durable disposition that informs interpretations of the past. This perspective on the past gains its emotional valence in part from the categorical thinking, the ontological resonance of imagining Crimean Tatars as a threat. Based on the interview data, it seems Crimea lacks the cognitive and affective foundation to formulate an inclusive and civil society. Here, the lack of both guilt and shame with respect to the 1944 deportation are significant.

If we place the Crimean Tatar experience in the framework of critical genocide studies, we see the struggle over the past in Crimea as a technology of power that has an ongoing capacity to restructure relations among the living. I have exposed part of the process through which the aftermath of genocide has become attenuated. More ethnography can clarify if we are witnessing the aftermath of genocide or its prelude. The desecration of graves, the graffiti on historic monuments, hateful discussions on Facebook and other social media, searches of homes, mosques and schools, and the exile and imprisonment of Crimean Tatar leaders beg that question.

The question of what will become of public memory in post-Ukrainian Crimea is an urgent one: will Crimea be obligated to exclusively valorize the Soviet past, or will it "unhide" the human and social costs associated with past victories? In the aftermath of genocide, the contents of Crimean Tatar memory and history continue to be eclipsed, and neostalinism thrives. Any attempt by the new authorities to see only one side of the historic coin will result in a flat and ultimately unsatisfying account of the past.

\section{Endnotes}

1 Alexander Laban Hinton, “Critical Genocide Studies," Genocide Studies and Prevention 7, 1 (April 2012): 4-15.

2 This figure is based on a survey that Crimean Tatars carried out in the first years of exile (Cemilev, personal interview, June 1995). According to NDVD estimates, 27 percent of the population perished in the first three years Nikolai Zemskov, 1995. "Spetsposelentsy iz Kryma: 1944-1956." [Special Settlers from Crimea 1944-1956] Krymskie Muzei 1/94 Simferopol, Tavria, 75.

3 Daniel Feierstein, Genocide as a Social Practice, trans. Douglas Andrew Town (New Brunswick: Rutgers University Press, 2014), 12. Ebook.

4 It is important here to avoid homogenizing or oversimplifying complex identities and loyalties. I use Russian sympathizers here because what united my informants were that they were Russian-speaking, of Russian or mixed Russian and Ukrainian ancestry, and sympathized with Russia.

5 Jan Plamper, The Stalin Cult: A Study in The Alchemy of Power (New Haven: Yale University Press, 2012$), 12$.

6 Nanci Adler, "Reconciliation with-or Rehabilitation of - the Soviet Past?” Memory Studies 5, 3 (2012), 328.

7 Johan Galtung, "After Violence: Reconstruction, Reconciliation, and Resolution," in Reconciliation, Justice, and Coexistence: Theory and Practice, ed. Abu-Nimer, Muhammed (Lanham, MD: Lexington Books, 2001), 3-23; L. Kriesberg, "Changing Forms of Coexistence," in Reconciliation, Justice, and Coexistence: Theory and Practice, ed. Muhammed Abu-Nimer (Lanham, Md.: Lexington Books, 2001); Barbara Tint, "History, Memory, and Intractable Conflict," Conflict Resolution Quarterly 27, 3 (2010): 239-256.

8 Adler, "Reconciliation," 328.

9 Adler, "Reconciliation," 336.

10 The treatment of the Ukrainian-speaking population of Crimea warrants a separate article of its own. Their relation to both the Crimean Tatars and the pro-Russia Russians is a complex outside the scope of an article focused on the genocide of the Crimean Tatars.

11 Molly Andrews, "Shaping History: Narratives of Political Change" (Cambridge: Cambridge University Press, 2007), 161. 
12 Janine Natalya Clark, “The 'Crime of Crimes': Genocide, Criminal Trials and Reconciliation, Journal of Genocide Research 14, 1 (2012): 55-77; Lyndsay McLean Hilker, "Everyday Ethnicities: Identity and Reconciliation Among Rwandan Youth," Journal of Genocide Research 11, 1 (2009): 81-100; Lars Waldorf, "Revisiting Hotel Rwanda: Genocide Ideology, Reconciliation, and Rescuers," Journal of Genocide Research 11, 1 (2009): 101-125; Eugenia Zorbas, “What Does Reconciliation After Genocide Mean? Public Transcripts and Hidden Transcripts in Post-genocide Rwanda," Journal of Genocide Research 11, 1 (2009): 127-147.

13 Foundation for Research and Support of Indigenous Peoples of Crimea, "Information Provided by the Government of Ukraine on the Implementation of the Concluding Observations of the Committee on the Elimination of Racial Discrimination" (27 August 2007) Doc CERD/C/UKR/CO/18/Add.1, p. 7.

14 Michel Foucault, Society Must be Defended: Lectures at the College de France 1995-1996, eds., Mauro Bertani and Alessandro Fontana, trans. David Macey (New York: Picador, 1997), 66-76.

15 Greta Uehling, Beyond Memory: The Crimean Tatars' Deportation and Return (New York: Palgrave Macmillan, 2004); Greta Uehling "Squatting, Self-Immolation, and the Repatriation of Crimean Tatars," Nationalities Papers 28 (2000): 317-342.

16 Interview, Crimean Tatar Mejlis, May 26, 2013.

17 Brian Glyn Williams, A Homeland Lost: Migration, the Diaspora Experience and the Forging of Crimean Tatar National Identity (Doctoral Dissertation, University of Wisconsin Madison 1999); Greta Uehling, Beyond Memory: The Deportation and Return of the Crimean Tatars (New York: Palgrave Macmillan, 2004); Uehling, "Squatting, SelfImmolation, and the Repatriation of Crimean Tatars," Nationalities Papers 28 (2000): 317-342; Greta Uehling, "The Crimean Tatar National Movement: Social Memory and Collective Action," in Globalizations and Social Movements, eds., John Guidry, Michael Kennedy, and Mayer N. Zald (Ann Arbor: University of Michigan, 2000).

18 The accomplishments of two decades of rigorous effort toward cultural and political revival are still being assessed, but the re-establishment of the Crimean Tatar political body, the Mejlis, from prerevolutionary times, the reopening of mosques and medrese, the resuscitation of traditional decorative arts, and the reestablishment of Crimean Tatar as a language of instruction in some schools stand out as achievements.

19 Having provided the first full exploration of the Crimean Tatars' narrative accounts in my first ethnography, Uehling 2004.

20 Uehling, “Beyond Memory,” 2004.

21 The mutual contestation that takes place when knowledges characterized by different normative frameworks are pushed up against each other and individuals are compelled to question each other's omissions, exclusions, and hegemonies. Jose Medina, "Toward a Foucaultian Epistemology of Resistance: Counter-Memory, Epistemic Friction, and Guerrilla Pluralism," Foucault Studies 12 (2011): 9-35.

22 Yuri Shevchuk, Harvard Ukrainian Research Institute Symposium, “Crimea: Whose Homeland?” Harvard University, May 19, 2014.

23 Greta Uehling, "The Release of Haytarma and its Aftermath" http://www.iccrimea.org/reports/kaytarmareview1.html.

24 Galenko cited in Gulnara Bekirova and Elvidin Chubarov, Толерантные Учебники - Толерантное Общество [Tolerant Textbooks - Tolerant Society] (Simferopol: Tezis, 2011), 19-20.

25 Katherine Verdery, The Political Lives of Dead Bodies (New York: Columbia University Press, 1994), 36.

26 Украинская Правда, The Crimean Tatars Dispersed Exhibition Dedicated to Stalin December 21, (2012) Available at http://ww.pravda.com.ua/rus/news/2012/12/21/6980227.

27 Interview, 25 May, 2014.

28 Levada Tsentr. "Rossiane o roli Stalina v istorii nashei strany," 21 December 2005.

29 Levada Tsentr. "Vydaiushchiesia liudi vsekh vremen i narodov," 10 June 2008.

30 Polly Jones, Myth, Memory, Trauma (New Haven: Yale University Press, 2013), 261.

31 Jones, Myth Memory, Trauma, 261.

32 Sigmund Freud, “Mourning and Melancholia," The Pelican Freud Library. Translated, J. Strachery, 11 (Harmondsworth: Penguin, 1984), 245-268. For the concept of geopolitical melancholia and post-colonial melancholia see Jacques Derrida, Specters of Marx: The State of the Debt, the Work of Mourning and the New International. Translated, P. Kamuf (New York: Basic Books, 1994); Paul Gilroy, After Empire. Melancholia or Convivial Culture (London: Routledge, 2004).

33 Jones, Myth Memory Trauma, 261.

34 Pierre Bourdieu, Outline of the Theory of Practice, trans., Richard Nice (Cambridge: Cambridge University Press, 1977), 82-83. 
35 Bourdieu, The Logic of Practice, trans., Richard Nice (Stanford: Stanford University Press, 1980), 54.

36 Pierre Bourdieu and Loic J.D. Wacquant, An Invitation to Reflexive Sociology (Chicago: University of Chicago Press, 1992), 20.

37 Alexander Hinton, Why Did They Kill?: Cambodia in the Shadow of Genocide (Berkeley and Los Angeles: University of California Press), 27.

38 My contact at the Russian society drew from the database of members to fill the age and gender quotas I requested. This selection is likely to be biased by her judgments about who would be a willing informant, and also availability in May and June 2013.

39 Susan Corbesero, “History, Myth, and Memory: A Biography of a Stalin Portrait,” Russian History 38 (2011), 58-84.

40 May 9 is also known as Victory Day because it celebrates the capitulation of Nazi Germany to the Soviet Union. In the days of the Soviet Union, the holiday was marked throughout the various Soviet Socialist republics and typically a non-working holiday.

41 Interview, 3 June, 2013.

42 Interview, 3 June, 2013.

43 Kathleen E. Smith, Remembering Stalin's Victims: Popular Memory and the End of the USSR (Ithica: Cornell University Press, 1996), 8.

44 Interview, 1 June, 2013.

45 Rory Finnin, "Forgetting Nothing, Forgetting No One: Boris Chichibabin, Viktor Nekipelov, and the Deportation of the Crimean Tatars," Modern Language Review 106, 4 (2011): 1124.

46 Verdery, The Political Lives of Dead Bodies (New York: Columbia University Press, 1999).

47 Interview, 30 May, 2013.

48 Interview, 30 May, 2013.

49 Office of the United Nations High Commissioner for Human Rights. "Report on the Human Rights Situation in Ukraine, 15 April, 2014."

50 Interview, 26 May, 2013.

51 Theodor. W Adorno, "Schuld und Abwehr, Eine Qualitative Analyse zum 'Gruppenexperiment,"' Soziologische Schriften II, Gesammelte Schriften 9. 2, ed. R. Tiedemann (Frankfurt/Main: Suhrkamp, 1955/1998), 121-325; Max Horkeimer. "Vorwort zu Paul Passings 'Vorgeschichte des Politischen Antisemitismus,"' in Gesammelte Schriften 8 (Frankfurt/Main: Fischer, 1959/1985), 126-130.

52 Alexander Mischerlich and Margaret Mitscherlich, The Inability to Mourn: Principles of Collective Behavior (New York: Grove Press, 1975); Katharina Rothe, "Anti-Semitism in Germany Today and the Intergenerational Transmission of Guilt and Shame," Psychoanalysis, Culture and Society 17, 1 (2012): 16-34.

53 Rothe, "Antisemitism in Germany," 10.

54 For example, a pervasive trope repeated in reference to Crimean Tatars by people who are referencing nothing more than hearsay, is that during the war, Crimean Tatars were seen with severed, still bleeding Russian heads tied to their belts.

55 Uehling, http://www.iccrimea.org/reports/kaytarma-review1.html

56 Dominick LaCapra, Representing the Holocaust: History, Theory, Trauma (Ithaca: Cornell University Press, 1994).

57 Donald Rayfield, "How the Crimean Tatars Have Survived," The Guardian 21 June 2014.

58 Rayfield, "How the Crimean Tatars have Survived."

59 Feierstein, Genocide as a Social Practice, 14.

60 Verdery, "The Political Lives of Dead Bodies," 12.

61 http://www.theguardian.com/world/2014/may/09/vladimir-putin-arrives-crimea-victory-day-ukraine

62 I am grateful to the anonymous reviewers for helping me to make this point more explicit.

63 Tok шоу Гравитация 'Запрет на митинг' Available at: http://atr.ua/video/2014-05-16-22-41-51-4040637 Last access 17 July 2014.

64 Interview, May 16, 2014. http://atr.ua/video/2014-05-16-22-41-51-4040637.

65 Priscilla Haynor, Unspeakable Truths: Transitional Justice and the Challenge of Truth Commissions (New York: Routledge, 2010).

66 http://www.hrw.org/news/2014/10/07/crimea-enforced-disappearances; Uehling, "'Crimeastan' Society for Cultural Anthropology Hot Spots," October 28, 2014 available at http://www.culanth.org/fieldsights/617crimeastan. 